\title{
PESANTREN SEBAGAI LEMBAGA PENDIDIKAN ISLAM ASLI INDONESIA
}

\author{
Muhammad Yunus
}

STAI Bumi Silampari Lubukinggau Indonesia Muhammadyunus@staibsllg.ac.id

\begin{tabular}{ll}
\hline & Abstrak \\
\hline Article History & This research is qualitative research in \\
Received : 10-07-2019 & the form of library studies. Data in this \\
Revised : 12-07-2019 & study were obtained from sources such as \\
Accepted: 15-07-2019 & history books and journal articles. Data \\
\hline Keywords : & collection is conducted by summarizing, \\
Pesantren & organizing and formulating expert \\
the genuine of & opinions contained in the written \\
islamic & documents of the three books, journals, \\
education & articles and others. There are five \\
Institute & elements that characterize Islamic \\
Indonesian & boarding schools. These five elements are \\
& the main requirements for defining a \\
& pesantren. (1) Kiyai as leaders of Islamic \\
& boarding schools, (2) santri who live in \\
dormitories and study with clerics (3) & dormitory as residence for santri (4) \\
& recitation as a form of teaching kyai to \\
& santri, and (5) mosques as centers of \\
& education and boarding school activities. \\
\hline
\end{tabular}

\section{Pendahuluan}

Salah satu media dakwah yang sejak awal telah dipergunakan dalam penyiaran dan penyebaran Islam adalah pendidikan. Melalui pendidikan umat Islam awal berlomba-lomba memperdalam pengetahuan agamanya, dan melalui pendidikan pula mereka menyebarluaskannya. Aktivitas ini dilakukan dengan penuh semangat dan dengan daya vitalitas yang tinggi, bahkan semangat dan vitalits itu masih terasa hingga sekarang ini. (Mundzirin Yusuf, 2006: 134)

Demikian juga keberadaan Islam dan perkembangnnya di wilayah Nusantara, Pendidikan merupakan media islamisasi yang sangat penting. Hal itu tidak hanya terjadi pada masa awal masuknya Islam dan penyebarannya saja, tetapi juga pada masa 
perkembangannya, bahkan hingga sekarang. (Mundzirin Yusuf, 2006: 134)

Namun seiring dengan derasnya arus global yang hampirhampir menyentuh setiap lini kehidupan termasuk didalamnya lapangan pendidikan membuat sebagian pendidikan Islam Indonesia mengalami disorientasi. Disorientasi itu dapat dilihat dari konsep modernisasi pesantren sebagai lembaga pendidikan Islam asli Indonesia. Menurut Anis Masykur kecenderungan Pesantren mengikuti trend yang katanya modern adalah sebuah ironi. Sebab label pesantren dengan ketradisionalannya ternyata menyimpan potensi kemoderenan yang telah melampaui zamannya. (Ms Anis Masykur, 2010: 134)

Banyak hal menarik yang muncul diseputar pendidikan Islam di Indonesia, tetapi makalah ini hanya memfokuskan pada kajian pesantren sebagai lembaga Pendidikan Islam Asli Indonesia.

\section{Metode Penelitian}

Penelitian ini adalah penelitian kualitatif dalam bentuk studi kepustakaan. Data dalam penelitian ini didapat dari sumber-sumber tertulis seperti buku-buku sejarah dan artikel jurnal. Pengumpulan data dilakukan dengan cara merangkum, mengorganisasilkan dan merumuskan pendapat-pendapat para ahli yang tertuang dalam dokumen tertulis sepert buku, jurnal, artikel dan lain-lain. Analisis data dalam penelitian ini menggunakan model Miles dan Huberman yang meliputi Reduksi data, display data, dilanjutkan dengan penarikan kesimpulan.

\section{Pembahasan}

\section{Sejarah perkembangan Pesantren Sebagai lembaga Pendidikan Islam Asli Indonesia}

Pondok pesantren adalah lembaga pendidikan indegenous Indonesia dan telah mengakar ditengah-tengah masyrakat Indonesia (Munir, 2014:11). Secara historis pesantren lebih awal tumbuh dan berkembang di Indonesia jauh sebelum Indonesia merdeka. Bahkan Pendidikan tradisional ini telah berdiri disejumlah daerah yang terkenal antara lain: Banten, Surakarta, Bangkalan, Tremas Pacitan, 
Tebuireng Jombang, Surabaya, Geresik, Cirebon, Semarang, Kendal, Yogyakarta, dan daerah-daerah lainnya (Affandi Mochtar, 2010: 13).

Ketika Malaka ditaklukkan portugis pada tahun 1511 M, maka banyak para ulama dan mubaligh-mubaligh Islam meninggalkan Malaka pindah keaceh. Disana mereka mendirikan pesantrenpesantren untuk menyiarkan agama Islam dan mendidik calon ulama dan fuqaha. Pendeknya sejarah Pesantren di Aceh pada zaman Iskandar Muda menempuh zaman keemasan sehingga menjadi masyhur kemana-mana, karena banyak alim ulama dan ahli sastra Islam di Indonesia (Mahmud Yunus, 2008: 189).

Dalam perkembangan selanjutnya, seiring dengan banyaknya santri yang telah menyelesaikan pendidikannya dipesantren lembaga pendidikan ini juga mengalami perkembangan yang semakin pesat. Sebab setiap santri yang telah lulus dari sebuah pesantren, setelah pulang umumnya juga mendirikan pesantren. Hal ini barangkali ada kaitannya dengan tradisi keilmuan pesantren yang lebih menekankan pada proses transfer ilmu dan nilai. Pendirian pesantren baru oleh para alumni pesantren dapat dipahami sebagai proses itu. Dengan demikian tersebarlah pesantren diberbagai daerah baik dijawa maupun diluar jawa (Mundzirin Yusuf, 2006: 134).

Pada tahun 1556 belanda mendarat dibanten yang dipimpin oleh Kornelis Dehoutman. Kedatangan bangsa kolonial itu membawa pengaruh besar terhadap proses pendidikan dan pengajaran Islam. Dibidang pendidikan, Belanda melakukan pembaharuan pendidikan dengan memperkenalkan system dan metode pendidikan baru. Namun apa yang mereka sebut sebagai pembaharuan itu tiada lain adalah kristenisasi dan westernisasi (Mundzirin Yusuf, 2006: 134).

Seiring dengan semakin banyaknya umat Islam yang tersdidik baik hasil didikan dalam negeri (Langgar dan Pesantren) maupun luar neger (Timur tengah: Kairo dan Mekkah), ditambah dengan pengaruh gelombang pembaharuan Islam yang sangat gencar dilakukan dinegeri-negeri Muslim di Timur Tengah, mendorong munculnya kesadaran para pendidik Islam di Indonesia untuk melakukan perubahan-perubahan. Demikian juga system pendidikan Belanda yang kala itu jauh lebih maju dan lebih modern, tampaknya juga menjadi pemicu munculnya kesadaran baru tersebut. Para ulama menyadari bahwa system pendidikan langgar dan pesantren tradisional sudah tidak begitu sesuai lagi dengan iklim Indonesia saat itu. Apa lagi jumlah murid semakin bertambah banyak. Oleh karena 
itu kemudian muncul gagasan tentang perlunya melakukan pengembangan dan pembaharuan pendidikan Islam di Indonesia. Realisasinya system pendidikan Madrasah yang berkembang didunia Islam pada umumnya dan system sekolah yang dikembangkan oleh pemerintah kolonial mulai dimasukkan kedalam system pendidikan Pesantren. Pada gilirannya system pendidikan halaqoh bergeser kearah system klasikal dengan unit-unit kelas dan sarana prasarana sebagaimana pada kelas-kelas pada sekolah-sekolah (Mundzirin Yusuf, 2006: 151).

\section{Karakteristik Pesantren Sebagai Lembaga Pendidikan Islam Asli Indonesia}

Menurut Anis Masykur dalam Modernisasi Pesantren menulis bahwa ada lima unsur yang menjadi ciri pondok pesantren. Kelima unsur ini menjadi syarat utama untuk pendefinisian sebuah pesantren. (1) Kiyai sebagai pimpinan pondok pesantren, (2) santri yang bermukim di asrama dan belajar kepad kiyai (3) asrama sebagai tempat tinggal para santri (4) Pengajian sebagai bentuk pengajaran kiyai terhadap santri, serta (5) masjid sebagai pusat pendidikan dan kegiatan pondok pesantren (Anis Masykur: 43). Namun demikian ada pula yang tidak seragam dalam menyebutkan kelima hal tersebut.

\section{Format Pesantren dalam Mengahadapi Tantangan Arus Globalisasi}

Eksistensi dan peran strategis pesantren kini dihadapkan pada tantangan baru sebagai akibat dari arus globalisasi. Tantangan tersebut digambarkan oleh Abudin Nata sebagai kecenderungan dunia gelobal. Selanjutnya Abudin Nata dalam Kapita Selekta Pendidikan Islam mneulis bahwa terdapat beberapa tantangan yang harus dihadapi oleh dunia pesantren saat ini. tantangan tersebut diantaranya: (1) Adanya penggunaan sains dan teknologi dalam kehidupan masyarakat yang mempengaruhi lahirnya pola komunikasi, interaksi, system pelayanan public, dan pelaksanaan berbagai kegiatan, (2) Masuknya nilai-nilai budaya modern (barat) yang bercorak matrealistik, hedonistik, dan sekuleristik yang menjadi penyebab terjadinya dekadensi moral (3) Interdependensi (kesalingtergantungan) antar negara yang menyebabkan terjadinya dominasi dan hegemoni negara kuat atas negara yang lemah (4) adanya kebijakan pasar bebas (free market) yang memasukkan 
pendidikan sebagai komoditas yyang diperdagangkan yang selanjutnya berpengaruh terhadap visi, misi, tujuan dan komponen lainnya (Abudi Nata, 2012: 312)

Berbeda dengan Abudin Nata, Munir justru menulis bahwa sejak beberapa dasawarsa terahir ini pesantren mulai menurun harganya dimata bangsa, masyarakat, keluarga dan anak muda. Pesantren dianggap kurang mampu memenuhi tantangan pembagunan, dan kurang mampu merespon kebutuhan kaum muda. Mereka dalam keadaan kebingugan, mereka lebih tertarik masuk ke pendidikan umum yang lebih menjanjikan lapangan pekerjaan. Namun demikian mereka masih tetap menaruh harapan kepada pesantren yang dapat menjanjikan moral yang sangat berguna dalam mengarungi kehidupan modern. Gambaran tentang keadaan ini seperti diungkapkan oleh Nurkholis Madjid :

Coba perhatikan para kiyai dikota-kota besar yang telah mengalami kenaikan status sosial (biasanya melalui jenjang politik), mereka lebih percaya menyekolahkan anak-anaknya disekolah umum daripada dipesantren sendiri. Kalau perlu mereka memasukkan putra-putrinya ini dibidang-bidang paling produktif seperti ekonomi, kedokteran dan tekhnik, sementara itu mereka membiarkan anak-anak desa dan orang-orang kecil tetap memasuki pesantren. Mungkin pengikutnya akan hilang tanpa peantren yang tradisional itu. Tetapi mereka tidak mau membayangkan bagaimana kalau putra-putri mereka sendiri masuk pesantren. Seolah-olah mereka berkata: "Cukuplah aku saja, anakku jangan (Munir: 12)

Dalam merespon berbagai tantang tersebut maka pesantren yang berada dibawah hegemoni NU segera melakukan modernisasi terhadap muatan kurikulumnya, yaitu dengan memasukkan mata pelajaran ilmu pengetahuan modern sambil tetap memelihara tradisinya yang asli. Dalam kaitan ini, pesantren yang berada dibawah naungan NU menggunakan kaidah al-Muhahfdatul alal al-Qadim alshalih wa al-akhdzu bi al-jadid al-ashlah, yakni memelihara tradisi lama yang masih cocok, dan mangadopsi inovasi baru yang lebih cocok lagi (Abudin Nata: 13)

Untuk lebih mendukung keberhasilannya dalam melakukan modernisasi dikalangan pesantren, NU membentuk berbagai lembaga yang secara sungguh-sungguh bekerja untuk itu. Diantara lembaga- 
lembaga tersebut adalah Forum Studi Agama dan social (FSAS) dijepara, Pusat Pengembangan Pondok Pesantren dan Madrasah (P3M) di jakarta, Lembaga Kajian Islam dan Sosial (LKIS). Melalui lembaga-lembaga ini diselenggarakan diskusi, rutin tentang agama, filsafat, budaya dan masyarakat, pelatihan dan seminar, penelitian penerbitan dan advokasi. Tema-tema yang dibicarakan adalah berkaitan dengan upaya mencari pemikiran Islam alternative dalam hubungannya dengan isu-isu kontemporer sepeti tentang demokrasi, HAM, pluralisme, lingkungan hidup, perdamaian, pemberdayaan ekonomi masyarakat dan lain sebagainya (Abudin Nata: 13).

Selain itu dunia pesantren melakukan inovasi terhadap muatan kurikulum dan kelembagaan pendidikannya, mulai dari yang bercorak salafiyah yang berbasis kitab kuning, hingga madrasah dinniyah, madrasah sebagai sekolah umum berciri khas agama, sekolah kejuaruan, akademi, sekolah tinggi, institut hingga universitas. Berbagai inovasi ini sudah ada didunia pesantren. Dengan adanya program yang demikian itu maka lulusan pesantren kini tidak hanya menguasai ilmu agama saja melainkan ilmu-ilmu modern, ilmu terapan, ketrampilan penguasaan teknologi modern, dan penguasaan terhadap isu-isu kontemporer dengan tidak meninggalkan tradisi utamanya. Dengan demikian pesantren kini ada yang bersipat tradisional da nada yang bersipat modern. (Abudin Nata: 13).

\section{Simpulan}

Pondok pesantren adalah lembaga pendidikan indegenous Indonesia dan telah mengakar ditengah-tengah masyrakat Indonesia. Secara historis pesantren lebih awal tumbuh dan berkembang di Indonesia jauh sebelum Indonesia merdeka.

Terdapat lima unsur yang menjadi ciri pondok pesantren. Kelima unsur ini menjadi syarat utama untuk pendefinisian sebuah pesantren. (1) Kiyai sebagai pimpinan pondok pesantren, (2) santri yang bermukim di asrama dan belajar kepad kiyai (3) asrama sebagai tempat tinggal para santri (4) Pengajian sebagai bentuk pengajaran kiyai terhadap santri, serta (5) masjid sebagai pusat pendidikan dan kegiatan pondok pesantren.

Dalam upaya mengatasi bebragai tantangan globalisasi, pesantren berpinsip mempertahankan tradisi lama yang baik dan mengadopsi inovasi baru yang lebih baik lagi. Dengan demikian 
pesantren kini ada yang bersipat tradisional dan ada yang bersipat modern dengan melakuakn inovasi terhadap muatan kurikulumnya 
118 Muhammad Yunus, Pesantren Sebagai Lembaga.....

\section{DAFTAR PUSTAKA}

Masykur Anis. 2010. Menakar Modernisasi Pendidikan Pesantren, Depok: Barnea Pustaka.

Munir. 2014. Ta'dib, jurnal pendidikan Islam, Vol VIII No 01 edisi Juni 2014.

Mochtar Affandi. 2010. Kitab Kuning dan Tradisi Akademk Pesanten, Bekasi: Pustaka Isfahan.

Nata Abudi. 2012. Kapita Selekta Pendidikan Islam, Jakarta: Rajawali Pers.

Yunus Mahmud. 2008. Sejarah Pendidikan Islam di Indonesi, Jakarta: PT Mahmud Yunus Wadzuriyyah. 